\title{
DISTRIBUTION OF CYANOBACTERIA AT THE GELADA CAVE (SPAIN) BY PHYSICAL PARAMETERS
}

\author{
Antonia Martínez and Antonia Dolores Asencio \\ Div. Botánica. Dpto. de Biología Aplicada. Universidad Miguel Hernández. Avda. Universidad, s/n.03202 Elche, Alicante, Spain, aasencio@umh.es
}

\begin{abstract}
As part of an extensive study of the caves in the Province of Alicante (SE Spain), the distribution of cyanobacteria and physical data for the Gelada Cave are presented. This cave is $9.4 \mathrm{~m}$ deep, 0.9 to $5.0 \mathrm{~m}$ high, $1.2 \mathrm{~m}$ wide, and is located in a karst region. Photon flux density, relative humidity, and temperature were measured, and the environmental ranges of conditions where growth occurred fluctuated between 0.0008 $0.06 \mu \mathrm{E} . \mathrm{m}^{-2} \mathrm{~s}^{-1}, 55.0-95.0 \%$ and $5.4-18.0{ }^{\circ} \mathrm{C}$, respectively. All the microorganisms determined from the Gelada Cave were cyanobacteria. Other frequently observed groups in caves, such as Bacillariophyta and Chlorophyta, were not detected because the cave was too weakly illuminated and dry. Cyanobacteria were found to be grouped as blue, brown, green, or gray patina according to the sampling sites and their constituent organisms. The primary common stress factor on the distribution of algal communities in the Gelada Cave is light shortage, followed by humidity, lack of nutrients, and temperature. Twenty-two epilithic cyanobacteria were identified, ten of which have not been previously reported in caves. The species studied are included in the Chroococcales order $(77.30 \%)$, followed by the Oscillatoriales order $(13.60 \%)$ and by the Nostocales $(4.55 \%)$ and Stigonematales $(4.55 \%)$ orders. The extreme values of the environmental parameters are presented for each taxon in this cave.
\end{abstract}

\section{INTRODUCTION}

Caves present a microclimate that is characterized not only by temperature and relative humidity values that remain nearly constant all year round, but also by a luminous intensity that varies from the entrance to the back of the cave.

There are data sets on algal flora in caves from many countries and most continents. However, little information is available about algal communities in Spanish caves, and even less about the environmental conditions they require (Aboal et al., 1994; Asencio and Aboal, 1996, 2000 a,b; Asencio et al., 1996; Beltrán and Asencio, in press, Cañaveras et al., 2001; Gracia-Alonso, 1974; HernándezMariné and Canals, 1994; Hernández-Mariné et al., 1999; Ruíz-Sánchez et al., 1991).

The purpose of this study conducted at the Gelada Cave was to characterize the cyanobacterial communities and to document their distribution within the cave in accordance with environmental conditions as part of an extensive study of caves in the Province of Alicante (SE Spain).

\section{Study Area}

The Gelada Cave is located in the Font Roja Nature Reserve $\left(38^{\circ} 38^{\prime} 51^{\prime \prime} \mathrm{N}, 0^{\circ} 32^{\prime} 46^{\prime \prime} \mathrm{W}\right)$ at an altitude of $1050 \mathrm{~m}$ in the municipality of Alcoy (Alicante, Spain). The climate of this region is Mediterranean, with continental and mountain influences depending on the altitude. Summers are dry with not excessively high temperatures, while winters are harsh with some snowfalls. Rainfall is relatively high and variable depending on exposure and altitude, with maximum precipitations in autumn $(46 \mathrm{~mm})$, winter $(39 \mathrm{~mm})$ and spring $(44 \mathrm{~mm})$, and minimum precipitations in summer $(10 \mathrm{~mm})$. The mean annual temperature is between $12{ }^{\circ} \mathrm{C}$ and $15{ }^{\circ} \mathrm{C}$. There are limestone rocks in the area dating back to the Tertiary.

The entrance to the cave (Fig. 1) faces north and is $9.4 \mathrm{~m}$ deep, 0.9 to $5.0 \mathrm{~m}$ high and $1.2 \mathrm{~m}$ wide.

\section{Material and Methods}

Prior to collecting from the surface of walls at nineteen points at the Gelada Cave where colonization was evident, photon flux density (Photosynthetically Active Radiation PAR), air temperature, and relative humidity measurements were taken in winter and summer. An LI-1400 datalogger model (LICOR) with an LI-192 sensor and a Delta Ohm HD $8501 \mathrm{H}$ thermohygrometer, were used. Electrodes were placed on the rock surface.

Samples were taken using a scalpel and were placed into labeled plastic bags. Scraped material was used directly for observation under a light microscope or as inoculate for cultures in BG11 medium (Rippka et al. 1979). The cultures were maintained at $25{ }^{\circ} \mathrm{C}, 70 \mu \mathrm{E} \cdot \mathrm{m}^{-2} \mathrm{~s}{ }^{-1}$, with a photoperiod of $16 \mathrm{~h}$ light and $8 \mathrm{~h}$ darkness. Species were determined by studying the material collected from the field and the cultured material.

\section{RESUlts AND DisCUSSION}

The mean relative humidity in the Gelada Cave was $81.0 \%$ in both summer and winter. Values ranging between 

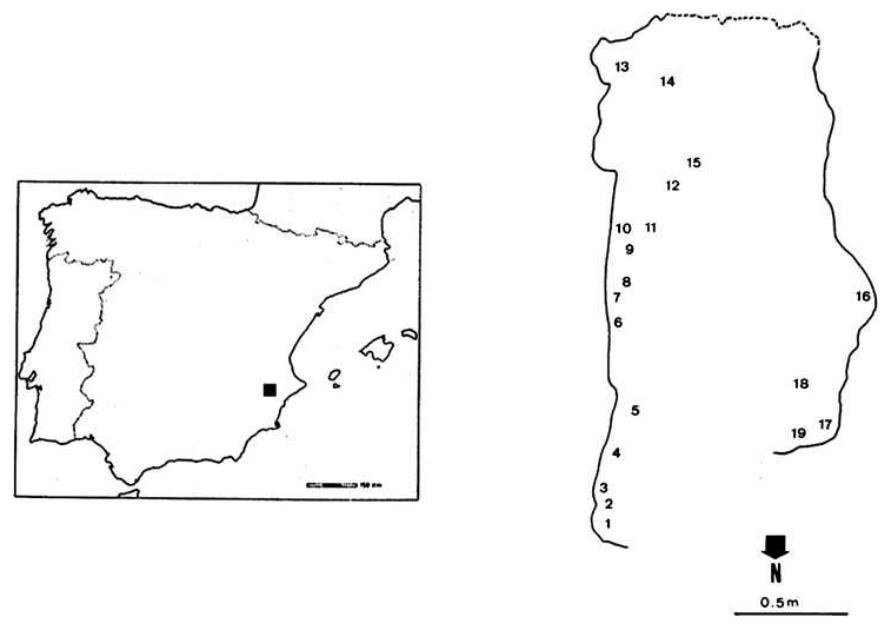

Figure 1. Geographical situation of Gelada Cave in Font Roja Nature Reserve in Alcoy, Alicante (SE Spain). Numbers show sampling sites.

a maximum of $95.0 \%$ inside the cave and a minimum of $55.0 \%$ at the entrance of the cave were recorded. These values coincide with the Quinçay Cave (Leclerc et al., 1983) and the Vapor Cave (Hernández-Mariné et al., 1999), however, they differ from those recorded at other areas in SE Spain, such as the Andragulla Shelter (Asencio and Aboal, 1996), the La Serreta Cave (Asencio and Aboal, 2000a) and the L'Aigua Cave (Beltrán and Asencio, in press), given the poor exposure of the area to the exterior, which modifies its environmental parameters.

The mean temperature in the Gelada Cave reaches 13.6 ${ }^{\circ} \mathrm{C}$ in summer and $6.2{ }^{\circ} \mathrm{C}$ in winter. Values ranging between a maximum temperature of $18.0{ }^{\circ} \mathrm{C}$ in summer and a minimum temperature of $5.4{ }^{\circ} \mathrm{C}$ in winter were recorded at points close to the entrance. The differences in temperature registered during the day varied between $1.7^{\circ} \mathrm{C}$ in summer and $1.2{ }^{\circ} \mathrm{C}$ in winter, which are similar to those recorded at Quinçay: $1{ }^{\circ} \mathrm{C}$ (Leclerc et al., 1983). These values differ from those recorded during the most extreme seasons at other areas in SE Spain, such as the Andragulla Shelter with a range of $20.6{ }^{\circ} \mathrm{C}$ to $6.0{ }^{\circ} \mathrm{C}$ (Asencio and Aboal, 1996), the La Serreta Cave with between $6.4{ }^{\circ} \mathrm{C}$ in summer and $3.8{ }^{\circ} \mathrm{C}$ in winter (Asencio and Aboal, 2000a), and the L'Aigua Cave with a range of $12.1{ }^{\circ} \mathrm{C}$ to $4.3{ }^{\circ} \mathrm{C}$ (Beltrán and Asencio, in press).

The mean PAR values recorded in the Gelada Cave reached $0.01 \mu \mathrm{E} . \mathrm{m}^{-2} . \mathrm{s}^{-1}$ in summer and $0.006 \mu \mathrm{E} . \mathrm{m}^{-2} . \mathrm{s}^{-1}$ in winter. Values ranging between a maximum of $0.06 \mu \mathrm{E} \cdot \mathrm{m}^{-2} . \mathrm{s}^{-1}$ in summer in the entrance and a minimum of $0.0008 \mu \mathrm{E} \cdot \mathrm{m}^{-2} \cdot \mathrm{s}^{-1}$ in winter inside the cave were recorded. These values were lower than those recorded at the Quinçay Cave where the maximum value reached was $0.2 \mu \mathrm{E} . \mathrm{m}^{-2} . \mathrm{s}^{-1}$ (Leclerc et al., 1983). These values differ from those recorded during the most extreme seasons at other areas in SE Spain, such as the Andragulla Shelter: $1504.0 \mu \mathrm{E} \cdot \mathrm{m}^{-2} \cdot \mathrm{s}^{-1}$ in summer and $1.4 \mu \mathrm{E} \cdot \mathrm{m}^{-2} \cdot \mathrm{s}^{-1}$ in winter (Asencio and Aboal, 1996), the La Serreta Cave: $1241.0 \mu \mathrm{E} \cdot \mathrm{m}^{-2} \cdot \mathrm{s}^{-1}$ in summer and $0.1 \mu \mathrm{E} \cdot \mathrm{m}^{-2} \cdot \mathrm{s}^{-1}$ in winter (Asencio and Aboal, 2000a), and the L'Aigua Cave: $1142 \mu \mathrm{E} . \mathrm{m}^{-2} . \mathrm{s}^{-1}$ in summer and $0.3 \mu \mathrm{E} . \mathrm{m}^{-2} . \mathrm{s}^{-1}$ in winter (Beltrán and Asencio, in press).

The fact that the relative humidity, temperature, and PAR values recorded inside the Gelada Cave remained more or less constant throughout the year indicates that this is, strictly speaking, a cave in accordance with Hoffmann (1989). This is in contrast to other caves and shelters in SE Spain, which present a less constant microclimate given their more direct exposure to the exterior (Asencio and Aboal, 1996; Asencio and Aboal, 2000a and Beltrán and Asencio, in press).

A total of twenty-two species have been identified and characterized along with the environmental parameters in the Gelada Cave (Appendix 1 and Table 1).

The cyanobacteria studied are included in the Chroococcales order, where the most diversity has been verified $(77.30 \%)$, followed by the Oscillatoriales order $(13.60 \%)$, then by the Nostocales (4.55\%) and Stigonematales (4.55\%) orders. The abundance of the Chroococcales species in the Gelada Cave, along with the predominance of Oscillatoriales, as opposed to Nostocales, coincides with some caves in Belgium (Garbacki et al., 1999) with similar temperature and humidity values.

Of the twenty-two species found, seventeen were coccoid and five were filamentous species. At sampling points $1,8,14,15,16$ and 17 , coccoid species were found exclusively. Coccoid species, as opposed to filamentous species, predominated at points 2, 3, 4, 5, 6, 7, 10 and 11 . Filamentous species, as opposed to coccoid species, predominated at points 9,13 and 18. A number of coccoid and filamentous species coincided at points 12 and 19. The predominance of coccoid species, as opposed to filamentous species, at the Gelada Cave coincides with the findings in the La Serreta Cave (Asencio and Aboal, 2000a), unlike caves and shelters that are not so deep and where filamentous species predominate (Asencio and Aboal, 1996). Coccoid forms are more abundant in dark areas, whereas filamentous forms tend to be more diverse in illuminated locations, unlike the findings of Vinogradova et al., (1998) who considered the opposite scenario.

The collected species are characterised by the presence of mucilaginous sheaths whose volume may vary considerably. Sheaths act as water reservoirs to avoid drying and prolong activity under drought conditions (Friedmann, 1972; Caiola et al., 1996; Nienow, 1996; Potts, 1999 and Potts and Friedmann, 1981). Occasionally, sheaths appear coloured because of pigments acting as filters to diminish the amount of incident light, which is in accordance with Krumbein and Potts (1978).

Of the thirteen identified genera, the genus that presents the most different species is Gloeocapsa with four, followed by Cyanosaccus and Leptolyngbya with three species each, then by Chroococcus and Pleurocapsa with two each. The 
Table 1. Location of cyanobacteria at Gelada Cave and environmental conditions showing maxima and minima of PAR, temperature, and relative humidity to which the different taxa grow. Numbers show sampling sites.

\begin{tabular}{|c|c|c|c|c|c|c|c|}
\hline \multirow[b]{2}{*}{ Cyanobacteria } & \multirow[b]{2}{*}{ Sampling Site } & \multicolumn{2}{|c|}{ P.A.R. $\left(\mu \mathrm{E} \cdot \mathrm{m}^{-2} \cdot \mathrm{s}^{-1}\right)$} & \multicolumn{2}{|c|}{ Temperature $\left({ }^{\circ} \mathrm{C}\right)$} & \multicolumn{2}{|c|}{$\begin{array}{l}\text { Relative Humidity } \\
(\%)\end{array}$} \\
\hline & & $\max$ & $\min$ & $\max$ & $\min$ & $\max$ & $\min$ \\
\hline Aphanothece saxicola & 6,10 & 0.004 & 0.0008 & 14.3 & 5.5 & 91.0 & 76.0 \\
\hline Asterocapsa divina & $1,2,3,4,5,6,7,8,11,13$ & 0.03 & 0.001 & 18.0 & 5.4 & 95.0 & 55.0 \\
\hline Chroococcidium sp & 4 & 0.01 & 0.004 & 16.0 & 5.4 & 84.0 & 77.0 \\
\hline Chroococcus spelaeus & $1,4,5,6,14$ & 0.02 & 0.003 & 18.0 & 5.4 & 92.0 & 55.0 \\
\hline Chroococcus westii & $6,7,8,14$ & 0.01 & 0.001 & 14.3 & 5.5 & 91.0 & 71.0 \\
\hline \multicolumn{8}{|l|}{ Cyanobacterium } \\
\hline cedrorum & 5 & 0.003 & 0.005 & 15.5 & 5.7 & 92.0 & 73.0 \\
\hline Cyanosaccus aegeus & $1,6,7,10,14$ & 0.02 & 0.0008 & 18.0 & 5.5 & 91.0 & 55.0 \\
\hline Cyanosaccus atticus & 11,18 & 0.03 & 0.002 & 13.4 & 5.6 & 90.0 & 71.0 \\
\hline Cyanosaccus sp & 3 & 0.03 & 0.002 & 16.4 & 5.6 & 80.0 & 78.0 \\
\hline \multicolumn{8}{|l|}{ Cyanostylon } \\
\hline microcystoides & $1,2,5,8$ & 0.03 & 0.001 & 18.0 & 5.7 & 92.0 & 55.0 \\
\hline Gloeocapsa biformis & $1,2,5,15$ & 0.03 & 0.002 & 18.0 & 5.5 & 92.0 & 55.0 \\
\hline Gloeocapsa nigrescens & 3 & 0.03 & 0.002 & 16.4 & 5.6 & 80.0 & 78.0 \\
\hline Gloeocapsa novacekii & $2,8,17$ & 0.03 & 0.0008 & 18.0 & 5.8 & 85.0 & 67.0 \\
\hline Gloeocasa rupicola & $6,12,15,17,19$ & 0.06 & 0.0008 & 14.3 & 5.5 & 91.0 & 69.0 \\
\hline \multicolumn{8}{|c|}{ Leptolyngbya "Albertanol } \\
\hline Kováčik-red" & $3,4,7,10,11,12$ & 0.03 & 0.0008 & 16.4 & 5.4 & 90.0 & 77.0 \\
\hline Leptolyngbya carnea & 9 & 0.003 & 0.001 & 12.3 & 6.3 & 86.0 & 82.0 \\
\hline \multicolumn{8}{|l|}{ Leptolyngbya } \\
\hline leptotrichiformis & $2,5,6,7,9,11,13,18$ & 0.03 & 0.001 & 17.5 & 5.5 & 95.0 & 67.0 \\
\hline Pleurocapsa sp & 16 & 0.009 & 0.0009 & 13.6 & 5.7 & 84.0 & 73.0 \\
\hline Pleurocapsa minor & $8,9,10,11$ & 0.008 & 0.0008 & 13.1 & 5.6 & 90.0 & 81.0 \\
\hline Pseudocapsa dubia & $1,2,3,4,8$ & 0.03 & 0.001 & 18.0 & 5.4 & 85.0 & 55.0 \\
\hline Scytonema julianum & $5,6,10,11,13,19$ & 0.06 & 0.0008 & 15.5 & 5.5 & 95.0 & 69.0 \\
\hline \multicolumn{8}{|l|}{ Symphyonema } \\
\hline cavernicolum & 18 & 0.03 & 0.002 & 13.4 & 5.8 & 83.0 & 71.0 \\
\hline
\end{tabular}

remaining genera: Aphanothece, Asterocapsa, Chroococcidium, Cyanobacterium, Cyanostylon, Pseudocapsa, Scytonema and Symphyonema presented one species each.

The fact that four Gloeocapsa species were present at the Gelada Cave indicates that the algal colonization on the walls is at an intermediate stage, and coincides with Fritsch (1907), Diels (1914), Häyren (1940), Garty (1990) and Pentecost (1992), who all considered these genera to be pioneers in rock colonization. This contrasts with similar works in which Gloeocapsa appears less abundantly (Iliopoulou-Georgoudaki et al., 1993, Asencio and Aboal, 2000a, and Beltrán and Asencio, in press).

Of the twenty-two species identified, the most common are Asterocapsa divina found at ten points, Leptolyngbya leptotrichiformis at eight points, and Scytonema julianum at six points, while Chroococcidium sp, Cyanobacterium cedrorum, Cyanosaccus sp, Gloeocapsa nigrescens, Leptolyngbya carnea, Pleurocapsa sp and Symphyonema cavernicolum were encountered at only one point each.
Those species which withstand less constant environmental conditions at the Gelada Cave are: Cyanosaccus aegeus $\quad\left(0.02-0.0008 \mu \mathrm{E} . \mathrm{m}^{-2} . \mathrm{s}^{-1}, \quad 91.0-55.0 \%, \quad 18.0\right.$ $\left.5.5{ }^{\circ} \mathrm{C}\right)$, Gloeocapsa novacekii $\left(0.03-0.0008 \mu \mathrm{E} . \mathrm{m}^{-2} . \mathrm{s}^{-1}\right.$, $\left.85.0-67.0 \%, 18.0-5.8{ }^{\circ} \mathrm{C}\right)$, Gloeocapsa rupicola $(0.06-$ $\left.0.0008 \mu \mathrm{E} . \mathrm{m}^{-2} \cdot \mathrm{s}^{-1}, 91.0-69.0 \%, 14.3-5.5{ }^{\circ} \mathrm{C}\right)$, Leptolyngbya "Albertano/Kováčik-red" (0.03-0.0008 $\mu \mathrm{E} \cdot \mathrm{m}^{-2} . \mathrm{s}^{-1}$, 90.0-77.0\%, 16.4-5.4 ${ }^{\circ} \mathrm{C}$ ) and Scytonema julianum (0.06$\left.0.0008 \mu \mathrm{E} . \mathrm{m}^{-2} . \mathrm{s}^{-1}, 95.0-69.0 \%, 15.5-5.5{ }^{\circ} \mathrm{C}\right)$, whereas Cyanobacterium cedrorum $\left(0.003-0.005 \mu \mathrm{E} . \mathrm{m}^{-2} . \mathrm{s}^{-1}, 92.0\right.$ $73.0 \%, 15.5-5.7{ }^{\circ} \mathrm{C}$ ) and Leptolyngbya carnea (0.003$0.001 \mu \mathrm{E} . \mathrm{m}^{-2} . \mathrm{s}^{-1}, \quad 86.0-82.0 \%, \quad 12.3-6.3{ }^{\circ} \mathrm{C}$ ) withstand more constant environmental conditions.

Scytonema julianum (Fig. 2) can resist extreme oscillations. It grows on well lit cave walls with maximum values of $2000 \mu \mathrm{E} . \mathrm{m}^{-2} \cdot \mathrm{s}^{-1}$ and under very low light conditions in some caves, where minimum values of $0.007 \mu \mathrm{E} \cdot \mathrm{m}^{-2} . \mathrm{s}^{-1}$ were registered (Leclerc et al., 1983; Couté and Bury 1988 and Aboal et al. 1994). 

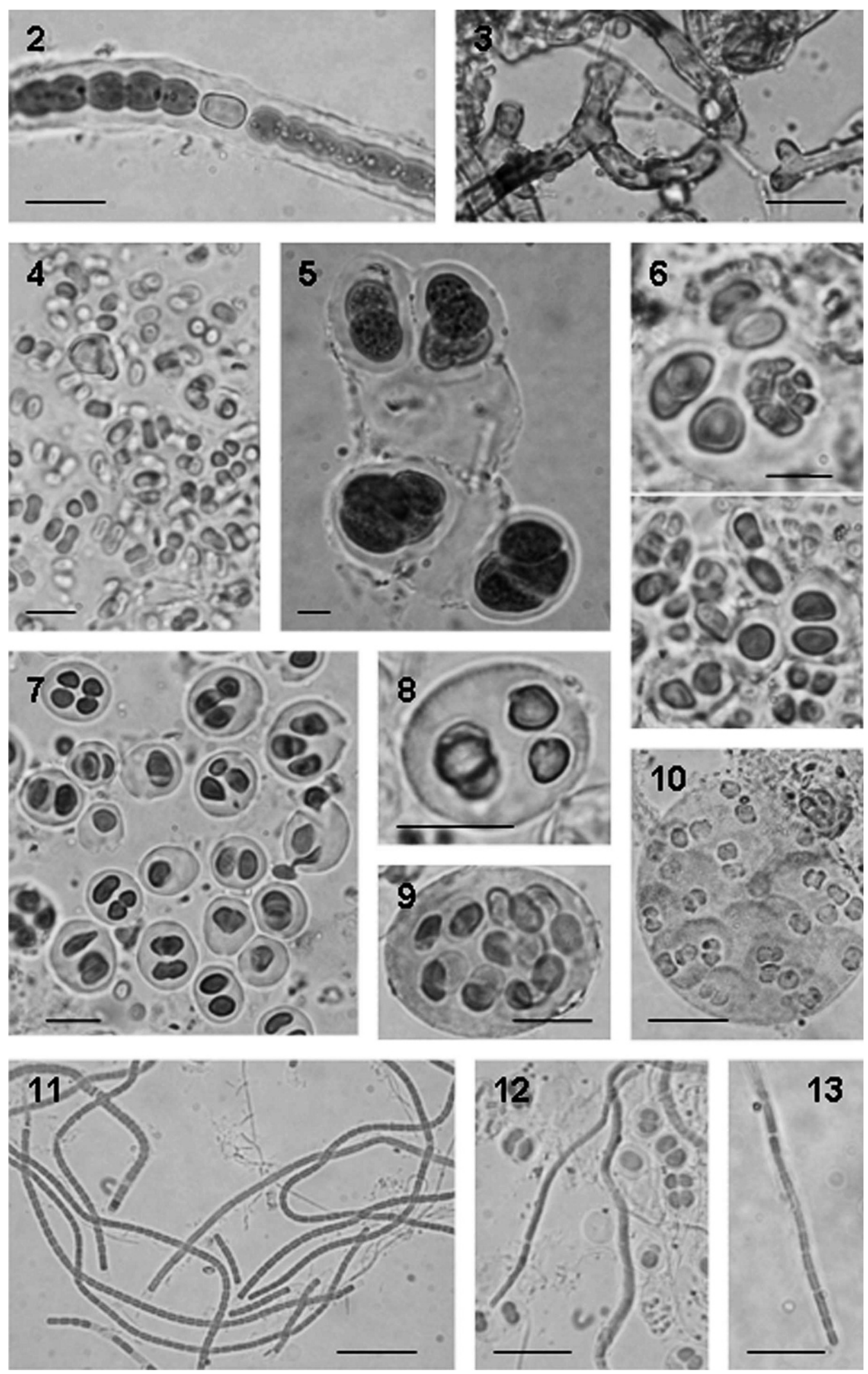

Plate 1. (Figures 2-13) Light micrographs [scale bar: $10 \mu \mathrm{m}$ ] of: 2- Scytonema julianum, 3- Symphyonema cavernicolum, 4Cyanobacterium cedrorum, 5- Cyanosaccus aegeus, 6- Cyanosaccus atticus, 7- Cyanostylon microcystoides, 8- Gloeocapsa nigrescens, 9- Gloeocapsa novacekii, 10- Gloeocapsa rupicola, 11- Leptolyngbya “AlbertanolKováčik-red”, 12- Leptolyngbya carnea, 13- Leptolyngbya leptotrichiformis. 

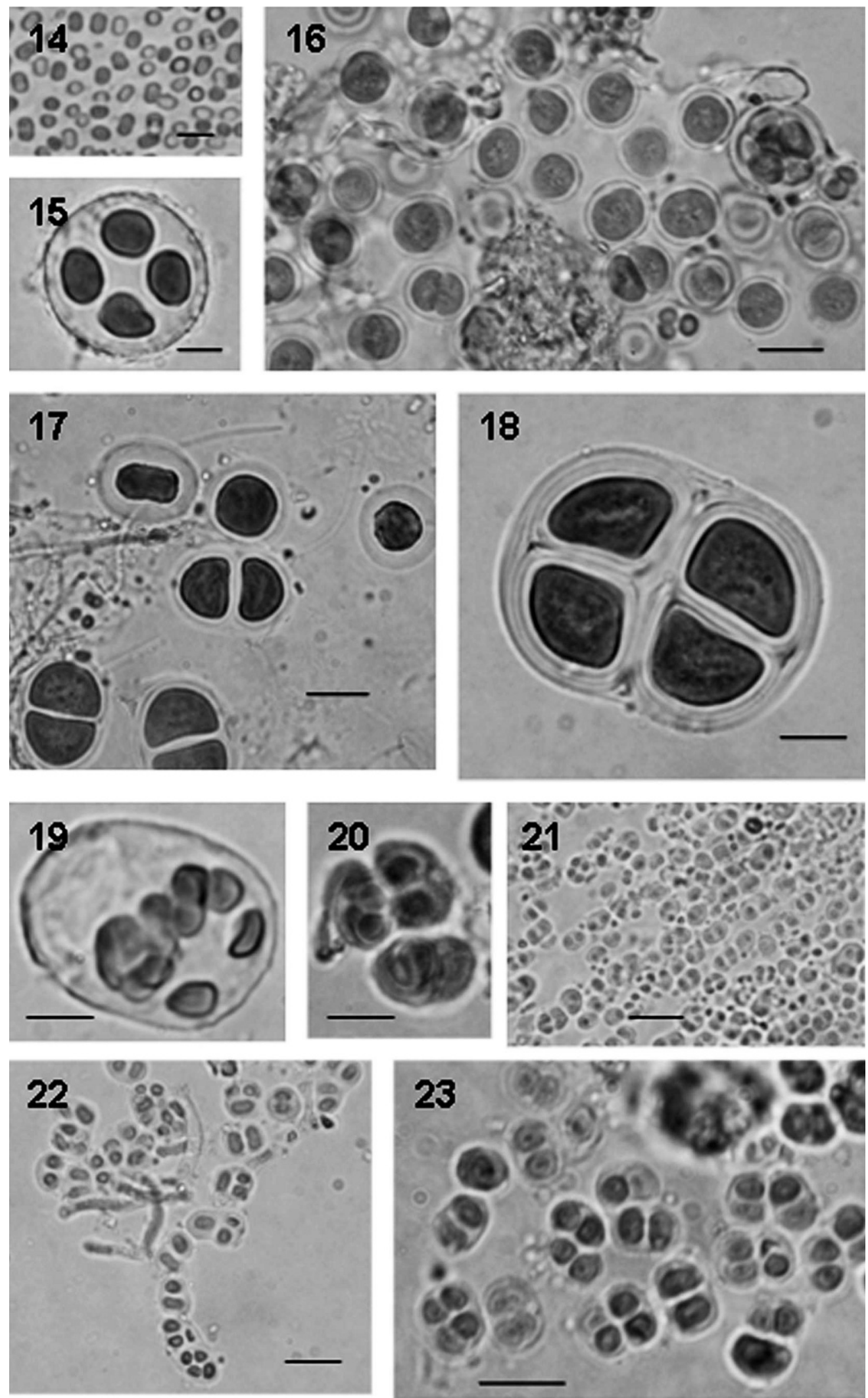

Plate 2. (Figures 14-23) Light micrographs [scale bar: $10 \mu \mathrm{m}$ ] of: 14- Aphanothece saxicola, 15- Asterocapsa divina, 16Chroococcidium sp, 17- Chroococcus spelaeus, 18- Chroococcus westii, 19- Cyanosaccus sp, 20- Gloeocapsa biformis, 21Pleurocapsa sp, 22- Pleurocapsa minor 23- Pseudocapsa dubia. 
Table 2. Characterization, composition and location of cyanobacteria communities at Gelada Cave. Numbers show sampling sites.

\begin{tabular}{|c|c|c|}
\hline Sampling Sites & Cyanobacterial Comunities & Patina \\
\hline 1 & $\begin{array}{l}\text { Asterocapsa divina, Chroococcus spelaeus, Cyanosaccus aegeus, } \\
\text { Cyanostylon microcystoides, Gloeocapsa biformis, Pseudocapsa dubia }\end{array}$ & greenish-bluish \\
\hline 2 & $\begin{array}{l}\text { Asterocapsa divina, Cyanostylon microcystoides, Gloeocapsa biformis, G. } \\
\text { novacekii, Leptolyngbya leptotrichiformis, Pseudocapsa dubia }\end{array}$ & greyish \\
\hline 3 & $\begin{array}{l}\text { Asterocapsa divina, Cyanosaccus sp, Gloeocapsa nigrescens, Leptolyngbya } \\
\text { "Albertano/Kováčik-red", Pseudocapsa dubia }\end{array}$ & greyish \\
\hline 4 & $\begin{array}{l}\text { Asterocapsa divina Chroococcidium sp, Chroococcus spelaeus, Leptolyngbya } \\
\text { "Albertano/Kováčik-red", Pseudocapsa dubia }\end{array}$ & greyish \\
\hline 5 & $\begin{array}{l}\text { Asterocapsa divina Chroococcus spelaeus, Cyanobacterium cedrorum, } \\
\text { Cyanostylon microcystoides, Gloeocapsa biformis, Leptolyngbya } \\
\text { leptotrichiformis, Scytonema julianum }\end{array}$ & bluish-greyish \\
\hline 6 & $\begin{array}{l}\text { Aphanothece saxicola, Asterocapsa divina, Chroococcus spelaeus, Ch. westii, } \\
\text { Cyanosaccus aegeus, Gloeocapsa rupicola, Leptolyngbya leptotrichiformis, } \\
\text { Scytonema julianum }\end{array}$ & bluish-greyish \\
\hline 7 & $\begin{array}{l}\text { Asterocapsa divina, Chroococcus westii, Cyanosaccus aegeus, Leptolyngbya } \\
\text { "Albertano/Kováčik-red", L. leptotrichiformis }\end{array}$ & brownish-grey \\
\hline 8 & $\begin{array}{l}\text { Asterocapsa divina, Chroococcus westii, Cyanostylon microcystoides, } \\
\text { Gloeocapsa novacekii, Pleurocapsa minor, Pseudocapsa dubia }\end{array}$ & greenish-bluish \\
\hline 9 & Leptolyngbya carnea, Leptolyngbya leptotrichiformis, Pleurocapsa minor & brownish-grey \\
\hline 10 & $\begin{array}{l}\text { Aphanothece saxicola, Cyanosaccus aegeus, Leptolyngbya "Albertanol } \\
\text { Kováčik-red", Pleurocapsa minor, Scytonema julianum }\end{array}$ & bluish-greyish \\
\hline 11 & $\begin{array}{l}\text { Asterocapsa divina, Cyanosaccus atticus, Leptolyngbya “Albertanol } \\
\text { Kováčik-red", Leptolyngbya leptotrichiformis, Pleurocapsa minor, } \\
\text { Scytonema julianum }\end{array}$ & bluish-greyish \\
\hline 12 & Gloeocapsa rupicola, Leptolyngbya "Albertano/Kováčik-red”' & brownish-grey \\
\hline 13 & Asterocapsa divina, Leptolyngbya leptotrichiformis, Scytonema julianum & bluish-greyish \\
\hline 14 & Chroococcus spelaeus, Chroococcus westii, Cyanosaccus aegeus & greenish-bluish \\
\hline 15 & Gloeocapsa biformis, Gloeocapsa rupicola & greenish-bluish \\
\hline 16 & Pleurocapsa $\mathrm{sp}$ & greenish-bluish \\
\hline 17 & Gloeocapsa novacekii Gloeocapsa rupicola & greenish-bluish \\
\hline 18 & $\begin{array}{l}\text { Cyanosaccus atticus Leptolyngbya leptotrichiformis and Symphyonema } \\
\text { cavernicolum. }\end{array}$ & brownish-grey \\
\hline 19 & Gloeocapsa rupicola Scytonema julianum & bluish-greyish \\
\hline
\end{tabular}

In contrast, other filamentous cyanobacteria, such as Symphyonema cavernicolum (Fig. 3), cited for the second time in such settings, require more stable temperature, relative humidity, and PAR values. This species at the Gelada Cave withstands PAR values below the minimum recorded at the La Serreta Cave during its epilithic development (Asencio and Aboal, 2000a). This confirms that this species does not withstand high light intensity values and implies that it develops chasmoendolithically when light peaks are very high (Asencio et al., 1996).

Of the twenty-two species identified, ten: Cyanobacterium cedrorum (Fig. 4), Cyanosaccus aegeus (Fig. 5), C. atticus (Fig. 6), Cyanostylon microcystoides (Fig. 7), Gloeocapsa nigrescens (Fig. 8), G. novacekii (Fig. 9), G. rupicola (Fig. 10), Leptolyngbya "Albertano/Kováčik-red" (Fig. 11), L. carnea (Fig. 12), and L. leptotrichiformis (Fig. 13) have not been previously cited in cave settings, but in places with weak incident radiation. Therefore, these results confirm the importance of light in the distribution of algae species and coincide with those of Jaag (1945) and Zehnder (1953).

Microscopic observations revealed that cyanobacteria are arranged in a particular assemblage named patinas which are blue, brown, green, or gray and continuous, and are arranged mosaically inside the Gelada Cave. These communities contain coccoid forms that are frequently accompanied by filamentous forms that are irregularly distributed and do not present stratification.

We may assume two different areas at the Gelada Cave. a) One area is the entrance level, where the microclimate is influenced by the exterior and attenuated light, temperature, and relative humidity fluctuate throughout the year. Patina is greenish-bluish formed by coccoid species only, and there are also grayish patina constituted by coccoid and filamentous species. b) The second area is the inside level with a 
stable temperature and relative humidity and very low light. The patina found are greenish-bluish formed by only coccoids species, brownish-gray patina constituted by coccoid forms and filamentous forms, and bluish-grayish patina formed by coccoid forms and filamentous forms where Scytonema julianum predominates.

The points in the Gelada Cave where the largest number of species grow were 6 and 5 with eight and seven species respectively, and the lowest number was at 16 with only one species (Table 2). The diversity of cyanobacteria communities diminishes with decreasing light.

The occurrence of a particular assemblage of cyanobacteria in the samples taken at the Gelada Cave suggests some stability of species composition in these communities. The network of filaments may contribute to maintain levels of moisture during periods in which the relative humidity of the air is low, thus favoring all community members.

There was a larger number of species growing at the sampling locations facing west given the presence of holm oaks, which prevent sun rays from passing to the sampling locations facing east. The primary common stress factor on the distribution of algal communities in the Gelada Cave is light shortage, followed by humidity, lack of nutrients and temperature, which is in accordance with Smith and Olson (2007) for cave-like environments.

\section{ACKNOWLEDGEMENTS}

We sincerely thank N. Espinosa, P. Espinosa, T. Espinosa and L. Serra for their help in the field and H. Warburton for his assistance in the English version of the text.

\section{REFERENCES}

Aboal, M., Asencio, A.D., and Prefasi, M., 1994, Studies on cave cyanophytes from southeastern Spain: Scytonema julianum Richter: Archiv für Hydrobiology Algological Studies, v. 75, p. 31-36.

Aboal, M., Asencio, A.D., and López-Jiménez, E., 2003, Morphological, ultrastructural and ecological study of Asterocapsa divina Komárek (Chroococcaceae, Cyanobacteria) from a cave of Southeastern Spain: Archiv für Hydrobiology/Algological Studies, v. 109, p. 57-65.

Anagnostidis, K., Economou-Amilli, A., and Pantazidou, A., 1981, Studies on the microflora of the cave Perama, Ioannina, Greece: Bulletin Society Speleological Greece, v. 18, p. 458-530.

Anagnostidis, K., and Pantazidou, A., 1985, Cyanosaccus aegaeus n. sp., a new marine endolithic cyanophyte from the Aegean Sea, Hellas (Greece): Archiv für Hydrobiology/Algological Studies, v. 38/39, p. $105-114$.

Anagnostidis, K., and Pantazidou, A., 1988, Endolithic cyanophytes from the saline thermal springs of Aedipsos, Hellas (Greece): Archiv für Hydrobiology/Algological Studies, v. 50-53, p. 555-559.

Ariño, X., Hernández-Mariné, M., and Saíz-Jiménez, C., 1997, Preliminary investigations on epilithic cyanophytes from a Roman necropolis: Archiv für Hydrobiology/Algological Studies, v. 75, p. 71-74.

Asencio, A.D., 1997, Flora algal y condiciones ambientales de las cuevas y abrigos con pinturas rupestres de la Región de Murcia (SE España). [Ph.D.thesis]: Universidad de Murcia, 382 p.

Asencio, A.D., and Aboal, M., 1996, Cyanophytes from Andragulla abrigo (Murcia, SE Spain) and their environmental conditions: Archiv für Hydrobiology/Algological Studies, v. 83, p. 55-72.

Asencio, A.D., Aboal, M., and Hoffmann, L., 1996, A new caveinhabiting blue-green alga: Symphyonema cavernicolum sp. nova
(Mastigocladaceae, Stigonematales): Archiv für Hydrobiology/Algological Studies, v. 83, p. 73-82.

Asencio, A.D., and Aboal, M., 2000a, Algae from La Serreta cave (Murcia, SE Spain) and their environmental conditions: Archiv für Hydrobiology/Algological Studies, v. 96, p. 59-72.

Asencio, A.D., and Aboal, M., 2000b, A contribution to knowledge of chasmoendolithic algae in cave-like environments: Archiv für Hydrobiology/Algological Studies, v. 98, p. 133-151.

Beltrán, J.A., and Asencio, A.D., 2009, Cyanophytes from the L'Aigua cave (Alicante, SE Spain) and their environmental conditions: Archiv für Hydrobiology/Algological Studies (in press).

Caiola, M.G., Billi, D., and Friedmann, E.I., 1996, Effect of desiccation on envelopes of the cyanobacterium Chroococcidiopsis sp (Chroococcales): European Journal of Phycology, v. 31(1), p. 97-105.

Cañaveras, J.C., Sánchez-Moral, S., Soler, V., and Saíz-Jiménez, C., 2001, Microorganisms and microbially induced fabrics in cave walls: Geomicrobiology Journal, v. 18, p. 223-240.

Chang, T.P., and Chang-Schneider, H., 1991, Algen in vier süddeutschen Höhlen: Berichte der Bayerischen Botanischen Gesellschaft, v. 62, p. $221-229$.

Couté, A., and Bury, E., 1988, Ultrastructure d'une cyanophycée aérienne calcifiée cavernicole: Scytonema julianum (Frank) Richter (Hormogonophycideae, Nostocales, Scytonemataceae): Hydrobiologia, v. 160, p. 219-239.

Diels, L., 1914, Die Algen Vegetation der südtiroler Dolomitriffe. Ein Beitrag zur Ökologie der Lithophyten: Verhandlungen der Deutschen Botanischen Gesellschaft, v. 32, p. 502-526.

Dor, I., and Dor, Y., 1999, Cyanobacterial flora of the Soreq stalactite Cave (Israel) and way of its control: Archiv für Hydrobiology/ Algological Studies, v. 129, p. 115-118.

Domínguez, S.G., and Asencio, A.D., 2009, Distribution of chasmoendolithic Cyanobacteria in gypsiferous soils from semi-arid environments (SE Spain) by chemicals and physical parameters: Nova Hedwigia, (in press).

Friedmann, E.I., 1972, Ecology of lithophytic algal habitats in Middle Eastern and North American deserts, in Rodin, L.E., ed., Ecophysiological foundation of ecosystems productivity in arid zones, Nauka, U.S.S.R. Academic Sciences, Leningrad, p. 182-185.

Friedmann, E.I., 1979, The genus Geitleria (Cyanophyceae or Cyanobacteria): Distribution of $G$. calcarea and G. floridana n. sp.: Plant Systematics and Evolution, v. 131, p. 169-178.

Fritsh, F.E., 1907, A general consideration of the subaerial and freshwater algal flora of Ceylon. A contribution to the study of tropical algal ecology. Part I. -Subaerial algae and algae of the inland freshwaters, in Proceedings of the Royal Society of London, v. 79, p. $197-254$

Garbacki, N., Ector, L., Kostikov, I., and Hoffmann, L., 1999, Contribution à l'étude de la flore des grottes de Belgique: Belgium Journal of Botany, v. 132, p. 43-76.

Garty, J., 1990, Influence of epilithic microorganisms on the surface temperature of building walls: Canadian Journal of Botany, v. 68, p. 1349-1353.

Golubic, S., 1967, Algenvegetation der Felsen, in Elster, H.J., and Ohle, W., eds., Die Binnengewässer: E. Schweizerbart'sche Verlagsbuchhandlung, Stuttgart, p. 23-183.

Gracia-Alonso, C.A., 1974, Geitleria calcarea Friedmann nueva alga cavernicola para España: Speleon, v. 21, p. 133-136.

Häyren, E., 1940, Die Algenvegetation der Sickerwasserstreifen auf den Felsen in Südfinnland: Societas Scientiarum Fennicae Commentationes Biologicae, v. 7, p. 1-19.

Hernández-Mariné, M., and Canals, T., 1994, Herpyzonema pulverulentum (Mastigocladaceae), a new cavernicolous atmophytic and limeincrusted cyanophyte: Archiv für Hydrobiology/Algological Studies, v. 75, p. $123-136$.

Hernández-Mariné, M., Asencio, A.D., Canals, A., Ariño, X., Aboal, M., and Hoffmann, L., 1999, Discovery of populations of the limeincrusting genus Loriella (Stigonematales) in Spanish caves: Archiv für Hydrobiology/Algological Studies, v. 94, p. 121-138.

Hoffmann, L., 1989, Algae of terrestrial habitats: Botanical Review, v. 55, p. $77-105$.

Iliopoulou-Georgoudaki, J., Pantazidou, A., and Theoulakis, P., 1993, An assessment of cleaning photoautotropic microflora: the case of Perama cave, Ioannina Greece: Mémories de Biospéologie, v. 20, p. $117-120$. 
Jaag, O., 1945, Untersuchungen über die Vegetation und Biologie der Algen des nackten Gesteins in den Alpen, im Jura und schweizerischen Mittelland: Beiträge zur Kryptogamenflora der Schweiz, v. 9, p. $1-560$.

Komárek, J., 1993, Validation of the genera Gloeocapsopsis and Asterocapsa (Cyanoprokaryota) with regard to species from Japan, Mexico and Himalayas: Bulletin National Science Museum, Tokyo, Ser. B, v. 19, p. 19-37.

Komárek, J., and Anagnostidis, K., 1999, Süsswasserflora von Mitteleuropa. Cyanoprokaryota 1. Chroococcales, Gustav Fischer Verlag, Stuttgart, Jena, New York, 548 p.

Komárek, J., and Anagnostidis, K., 2005, Cyanophyta part II: Oscillatoriales, in, Büdel, B., Gärtner, G., Krienitz, L., and Schagerl, M., eds., Süsswasserflora von Mitteleuropa 19/2: 1-759, Gustav Fischer, Jena,

Krumbein, W.E., and Potts, M., 1978, Light penetration, salinity and other growth regulating factors of four stromatolitic environments along the shores of the Gulf of Aqaba (Sinai), in: Friedmann, G.M., ed., Abstracts $10^{\text {th }}$ International Congress on Sedimentology 1. Jerusalem. 363 p.

Leclerc, J.C., Couté, A., and Dupuy, P., 1983, Le climat annuel de deux grottes et d'une église du Poitou, où vivent des colonies pures d'algues sciaphiles: Cryptogamie, Algologie, v. 4, p. 1-19.

Margalef, R., 1952, Algas de agua dulce del noroeste de España: Publicaciones del Instituto de Biología Aplicada, v. 22, p. 43-152.

Nienow, J.A., 1996, Ecology of subaerial algae: Nova Hedwigia, v. 112, p. $537-552$.

Palik, P., 1938, Adatok a Bukk-Hegység Lithophyta Algavegetátiójához. (Beiträge zur Kenntnis der Lithophyten Algenvegetation des Bükkgebirges): Index Horti Botanici Universitatis Budapestinensis, v. 3, p. 3-10.

Pentecost, A., 1992, A note on the colonization of limestone rocks by Cyanobacteria: Archiv für Hydrobiology, v. 124, p. 167-172.

Poulicková, A., and Hasler, P., 2007, Aerophytic diatoms from caves in central Moravia (Czech Republic): Preslia, v. 79, p. 185-204.

Potts, M., 1999, Mechanisms of desiccation tolerance in cyanobacteria: European Journal of Phycology, v. 34, p. 319-328.

Potts, M., and Friedmann, E.I., 1981, Effects of water stress on cryptoendolithic cyanobacteria from hot desert rocks: Archiv für Mikrobiologie, v. 130, p. 267-271.

Rifón-Lastra, A.B., 2000, Algas epilíticas en monumentos de interés histórico de Galicia. [Ph.D.thesis], Universidade da Coruña, 282 p.

Rippka, R., Deruelles, J., Waterbury, J.B., Herdman, M., and Stanier, R.Y., 1979, Generic assignments, strain histories and properties of pure cultures of cyanobacteria: Journal of General Microbiology, v. 111, p. 1-61.

Ruíz-Sánchez, I., Marín-Girón, F., Ojeda, F., Marín-Olalla, F., Berros, J., and Marín-Olalla, E., 1991, Estudio macroscópico "in situ" y microscópico-ecológico de pequeñas zonas de flora verde (algas verdes y verdeazuladas) del interior de la Cueva de Nerja, in: Marín, F., and Carrasco, F., eds., Investigación biológica y edafológica de la cueva de Nerja, Trabajos sobre la cueva de Nerja, v. 2, p. 113-125.

Seckt, H., 1938, Estudios hidrobiológicos en la Argentina. Schizophyceae: Boletín de la Academia Nacional de Ciencias de Córdoba, v. 25, p. $383-429$.

Skuja, H., 1970, Alghe cavernicole nelle zone illuminate delle grotte di Castellana (Murge di Bari).-Le Grotte d'Italia, Ser. 4, v. 2, p. 193-202.

Smith, T., and Olson, R., 2007, A taxonomic survey of lamp flora (Algae and Cyanobacateria) in electrically lit passages within Mammoth cave national park, Kentucky: International Journal of Speleology, v. 36, p. $105-114$.

Uher, B., and Kovacik, L., 2002, Epilithic cyanobacteria of subaerial habitats in National Park Slovak Paradise (1998-2000): Bulletin Slovenskej Botanickej Spoločnosti Bratislava, v. 24, p. 25-29.

Uher, B., Aboal, M., and Kovacik, L., 2005, Epilithic and chasmoendolithic phycolflora of monuments and buildings in South-Eastern Spain: Cryptogamie, Algologie, v. 26(3), p. 275-358.

Vinogradova, O.N., Kovalenko, O.V., Wasser, S.P., Nevo, E., and Weinstein-Evron, M., 1998, Species diversity gradient to darkness stress in blue-green algae/cyanobacteria: a microscale test in a prehistoric cave, Mount Carmel, Israel: Israel Journal of Plant Sciences, v. 46, p. 229-238.

Zehnder, A., 1953, Beitrag zur Kenntnis von Mikroklima und Algenvegetation des nackten Gesteins in den Tropen: Berichte der Schweizerischen Botanischen Gesellschaft, v. 63, p. 5-26.

\section{APPENDIX 1. \\ TAXONOMIC LIST OF CYANOBACTERIAL FLORA FROM GELADA CAVE}

Aphanothece saxicola Nägeli

Fig. 14

Cylindrical cells, 2.0-3.0 $\mu \mathrm{m}$ wide and 2.5-3.5 $\mu \mathrm{m}$ long, grouped in a gelatinous mass with no clear shape. With the sheath, they can become 2.5-3.5 $\mu \mathrm{m}$ wide and 3.0-4.0 $\mu \mathrm{m}$ long. This species was cited by Seckt (1938), Margalef (1952), Dor and Dor (1999), Smith and Olson (2007) and by Beltrán and Asencio (in press) as an epilithic species on cave walls.

Asterocapsa divina Komárek

Fig. 15

Spherical cells, 4.0-5.0(-6.0) $\mu \mathrm{m}$, surrounded by a hyaline sheath, ornamented with wart-like structures, reaching a diameter of $6.5-8.0(-9.0) \mu \mathrm{m}$. They group to form colonies reaching $30.0 \mu \mathrm{m}$. Komárek (1993) described this species on limestone rocks in Mexico. Aboal et al (2003) found this species in a cave in Murcia, Spain.

\section{Chroococcidium sp}

Fig. 16

Spherical, bluish-greenish $7.6 \mu \mathrm{m}$-diameter cells, which may form groups as colonies of up to $14.0 \mu \mathrm{m}$. They are arranged as an undefined gelatinous mass.

Chroococcus spelaeus Ecergovic

Fig. 17

Spherical, 9.0-10.0 $\mu \mathrm{m}$-diameter, violet or dark green cells surrounded by a hyaline sheath which reaches $15.0 \mu \mathrm{m}$. After division, groups of 2-4 cells appear with a diameter of up to $20.0 \mu \mathrm{m}$. Komárek and Anagnostidis (1999) cited this species as aerophytic, and they found it on humid rocks in Croatia. Poulíčková and Hašler (2007) noticed it in caves in the Czech Republic.

Chroococcus westii Boye-Petersen

Fig. 18

Violet spherical cells of $11.0 \mu \mathrm{m}$ diameter, surrounded by a lamellate hyaline sheath reaching $15.0 \mu \mathrm{m}$. After division, groups of 2 to 4 cells appear to reach a diameter of 20.0 $25.0 \mu \mathrm{m}$. Komárek and Anagnostidis (1999) cited this species as subaerophytic and found it on humid rocks in mountainous areas. Garbacki et al (1999) referred to it in caves in Belgium.

Cyanobacterium cedrorum (Sauvageau) Komárek et al.

Fig. 4

Cylindrical bluish-greenish cells, either alone or in pairs, $4.5 \mu \mathrm{m}$ long and $2.0 \mu \mathrm{m}$ wide.

Komárek and Anagnostidis (1999) cited this species as being subaerophytic on humid rocks of warm areas of the temperate zone and in tropical countries. Uher et al (2005) noted it on monuments in Murcia, Spain.

\section{Cyanosaccus sp}

Fig. 19

Spherical or pyriform purple cells, $6.0 \mu \mathrm{m}$. They are single or form groups of $2-4$, surrounded by a gelatinose, hyaline, penduculated glass-shaped sheath of up to $20.0 \mu \mathrm{m}$ wide. Presence of spherical nanocytes, 2.5(-3.0) $\mu \mathrm{m}$ diameter.

Cyanosaccus aegeus Anagnostidis et Pantazidou Fig. 5 Ellipsoidal or pyriform violet cells with a granular content, measuring $12.0 \times 9.0 \mu \mathrm{m}$. They are single or form groups of $2-4$, surrounded by a mucilaginous, colourless and 
penduculated sheath. These structures, measuring as much as $37.0 \mu \mathrm{m}$ wide, form groups of 4 and appear dendriform. Anagnostidis and Pantazidou (1985) described this species as endolithic on carbonate rocks of the Aegean Sea. Komárek and Anagnostidis (1999) cited it on the coast of South Africa.

Cyanosaccus atticus Anagnostidis et Pantazidou Fig. 6 Spherical or pyriform purple cells of around $5.4 \mu \mathrm{m}$. They are single or form groups of 2 to 4 , surrounded by a mucilaginous, hyaline and pedunculated sheath of up to 15.0-20.0 $\mu \mathrm{m}$ wide. Presence of spherical, 1.5(-2.0) $\mu \mathrm{m}$ diameter nanocytes. Anagnostidis and Pantazidou (1988) described this species as endolithic on carbonated rocks of the Aegean Sea.

Cyanostylon microcystoides Geitler

Fig. 7

Reddish, spherical $4.0 \mu \mathrm{m}$-diameter cells which are either alone or form groups of 2-4 cells, surrounded by a mucilaginous and hyaline sheath which extends to become penduculated. Komárek and Anagnostidis (1999) referred to this species on the walls of alpine lakes and waterfalls in Central Europe.

Gloeocapsa biformis Ecergovic

Fig. 20

Bluish-greenish spherical cells with a diameter of 3.0 $4.0 \mu \mathrm{m}$, surrounded by a hyaline or yellowish sheath that reach up to 5.0-6.0 $\mu \mathrm{m}$. Golubic (1967) found this species inside a cave in Croatia. Anagnostidis et al. (1981) mentioned it in the Perama Cave at Ioannina in Greece. Chang and Chang-Schneider (1991) found it in caves in Germany, while Ilipoulou-Georgoudaki et al. (1993) referred to it in a cave in Greece. Asencio and Aboal (1996) found it in a cave in Murcia, Spain. Garbacki et al. (1999) cited it in a cave in Belgium, whereas Beltrán and Asencio (in press) noticed it in a cave in Alicante, Spain.

Gloeocapsa nigrescens Nägeli in Rabenhorst

Fig. 8 Spherical cells, 4.0-5.0 $\mu \mathrm{m}$, surrounded by a reddish sheath reaching $6.0-7.0 \mu \mathrm{m}$. They group to colonies with a diameter of 10.0-20.0 $\mu \mathrm{m}$. Komárek and Anagnostidis (1999) cited this species as aerophytic on calcareous rocks in poorly illuminated areas and with a high atmospheric humidity. It was cited by Uher and Kováčik (2002) in epilithic subaerial populations of Slovakia.

Gloeocapsa novacekii Komárek et Anagnostidis Fig. 9 Spherical cells, $5.2 \mu \mathrm{m}$, surrounded by a hyaline or dark red-coloured sheath reaching $6.5 \mu \mathrm{m}$, which groups to form colonies, $11.0-35.0 \mu \mathrm{m}$, with colourless or reddish mucilaginous, non-lamellated sheaths. Komárek and Anagnostidis (1999) referred to this species as aerophytic on periodically dampened serpentine rocks in the Czech Republic. Rifón-Lastra (2000) cited on monuments of historic interest in Galicia, Spain. Domínguez and Asencio (in press) also cited it in gypsum areas of Alicante, Spain. Gloeocapsa rupicola Kützing

Fig. 10

Bluish-greenish spherical cells measuring 3.0-4.0 $\mu \mathrm{m}$, surrounded by a lamellated, $6.0 \mu$ m-diameter reddish sheath. They may group to form colonies measuring 35.0-50.0 $\mu \mathrm{m}$. Komárek and Anagnostidis (1999) described this species as being aerophytic on periodically dampened rocks and on mountain walls in Central Europe. Domínguez and Asencio (in press) cited it in gypsum areas of Alicante, Spain.

Leptolyngbya "AlbertanolKováčik-red"

Fig. 11

Filaments with a diameter of $3.0 \mu \mathrm{m}$ formed by a hyaline sheath and a constricted trichome formed by $2.0 \mu \mathrm{m}$ diameter and $2.0 \mu \mathrm{m}$-long brownish-reddish cells. Conical apical cell. Komárek and Anagnostidis (2005) cited this species as subaerophytic on humid walls of poorly illuminated areas.

Leptolyngbya carnea (Kützing ex Lemmermann) Anagnostidis et Komárek

Fig. 12 Densely interwoven filaments, $4.0 \mu \mathrm{m}$, made up of a hyaline sheath and non-constricted trichome with reddish $3.0 \mu \mathrm{m}$ isodiameterical cells. Rounded apical cell. Uher and Kováčik, (2002) cited this species in subaerial epilithic habitats in Slovakia. Komárek and Anagnostidis (2005) noted it as a subaerophytic species on the walls of greenhouses and on drenched rocks in Central Europe and in North America.

Leptolyngbya leptotrichiformis (Krieger) Anagnostidis et Komárek in Anagnostidis

Fig. 13

Filaments, 2.0-3.0 $\mu \mathrm{m}$ wide, with a hyaline sheath which surrounds the trichome made up of cells that are longer than they are wide, $2.0 \mu \mathrm{m}$ long and $1.0 \mu \mathrm{m}$ wide. Rounded apical cell. Komárek and Anagnostidis (2005) cited this species as an aerophytic species on walls made out of humid rocks in Greece.

\section{Pleurocapsa sp}

Fig. 21

Colonies made up of bluish-greenish pseudofilaments, 3.0 $4.0 \mu \mathrm{m}$, joined laterally by gelatinous hyaline sheaths. Rounded $2.0 \mu \mathrm{m}$-diameter cells. Nanocytes, $0.8 \mu \mathrm{m}$, group as cenobio with a diameter of $5.0 \mu \mathrm{m}$.

Pleurocapsa minor Hansgirg

Fig. 22

Colonies formed of bluish-greenish pseudofilaments with a diameter of 3.0-9.0 $\mu \mathrm{m}$ with gelatinous hyaline sheaths which surround the 3.0-4.0 $\mu \mathrm{m}$-diameter cells. This species has been cited in the Perama Cave at Ioannina in Greece (Anagnostidis et al., 1981). It has also been observed in the L'Aigua Cave in Alicante, Spain (Beltrán and Asencio, in press).

Pseudocapsa dubia Ercegovic

Fig. 23 Spherical cells of a $4.0 \mu \mathrm{m}$ diameter surrounded by a hyaline sheath, reaching a size of $5.0 \mu \mathrm{m}$. Cells vary in number and group in more or less rounded colonies, reaching 11.0-19.0 $\mu \mathrm{m}$. Nanocytes with a diameter of 1.5$2.0 \mu \mathrm{m}$. Palik (1938) mentioned Pseudocapsa dubia in a cave in Hungary and Skuja (1970) observed it in a cave in Italy. Ariño et al. (1997) found it on Roman tombs in Seville, Spain, while Asencio (1997) cited it as an epilithic and casmoendolithic species in several caves in Murcia, Spain. It also appeared in the L'Aigua Cave in Alicante, Spain (Beltrán and Asencio, in press).

Journal of Cave and Karst Studies, April 2010 •19 
Scytonema julianum (Meneghini ex Frank) Richter Fig. 2 Greenish-bluish filament, $10.5 \mu \mathrm{m}$ wide, surrounded by a considerably thick calcium carbonate sheath with which the filament reaches $13.0 \mu \mathrm{m}$. Hyaline sheath. Trichome formed by cells measuring 5.5-6.5 $\mu \mathrm{m}$ wide by $5.0-6.0 \mu \mathrm{m}$ long. Rectangular heterocytes $(5.0 \mu \mathrm{m} \times$ $7.0 \mu \mathrm{m})$. Friedmann (1979) cited this species on the walls of calcareous caves. Couté and Bury (1988) found it in numerous calcareous caves in France, while Hoffmann (1989) considered it characteristic of areas close to cave entrances. Iliopoulou-Georgoudaki et al. (1993) referred to it in a cave in Greece and Aboal et al. (1994) found it in a cave in Murcia, Spain. Ariño et al (1997) also cited it on Roman tombs in Seville, Spain. Cañaveras et al
(2001) found it in caves at Altamira and Tito Bustillo, Santander, Spain, whereas Smith and Olson (2007) mentioned it in a cave in Kentucky, USA. Finally, Beltrán and Asencio (in press) found it at the L'Aigua Cave in Alicante, Spain.

Symphyonema cavernicolum Asencio, Aboal and Hoffmann

Fig. 3

Filaments, diameter $5.0 \mu \mathrm{m}$, made up of constricted trichomes with tapering ends and with brownish cells measuring $4.0 \mu \mathrm{m}$ wide and $11.0 \mu \mathrm{m}$ long, surrounded by a hyaline sheath with calcium carbonate incrustations. They present genuine $\mathrm{V}$-, $\mathrm{Y}$ - and $\mathrm{T}$-shaped branches (infrequent). This species was described by Asencio et al. (1996) in cave settings in Murcia, Spain. 